\title{
Innovative power of Dutch secondary education
}

Citation for published version (APA):

Haelermans, C. (2010). Innovative power of Dutch secondary education. Innovation-Management Policy \& Practice, 12(2), 154. https://doi.org/10.5172/impp.12.2.154

Document status and date:

Published: 01/01/2010

DOI:

10.5172/impp.12.2.154

Document Version:

Publisher's PDF, also known as Version of record

Document license:

Taverne

\section{Please check the document version of this publication:}

- A submitted manuscript is the version of the article upon submission and before peer-review. There can be important differences between the submitted version and the official published version of record.

People interested in the research are advised to contact the author for the final version of the publication, or visit the DOI to the publisher's website.

- The final author version and the galley proof are versions of the publication after peer review.

- The final published version features the final layout of the paper including the volume, issue and page numbers.

Link to publication

\footnotetext{
General rights rights.

- You may freely distribute the URL identifying the publication in the public portal. please follow below link for the End User Agreement:

www.umlib.nl/taverne-license

Take down policy

If you believe that this document breaches copyright please contact us at:

repository@maastrichtuniversity.nl

providing details and we will investigate your claim.
}

Copyright and moral rights for the publications made accessible in the public portal are retained by the authors and/or other copyright owners and it is a condition of accessing publications that users recognise and abide by the legal requirements associated with these

- Users may download and print one copy of any publication from the public portal for the purpose of private study or research.

- You may not further distribute the material or use it for any profit-making activity or commercial gain

If the publication is distributed under the terms of Article $25 \mathrm{fa}$ of the Dutch Copyright Act, indicated by the "Taverne" license above, 


\title{
Innovation
}

\author{
Management, Policy \& Practice
}

ISSN: 1447-9338 (Print) 2204-0226 (Online) Journal homepage: https://www.tandfonline.com/loi/rimp20

\section{Innovative power of Dutch secondary education}

\section{Carla Haelermans}

To cite this article: Carla Haelermans (2010) Innovative power of Dutch secondary education, Innovation, 12:2, 154-165, DOI: 10.5172/impp.12.2.154

To link to this article: https://doi.org/10.5172/impp.12.2.154

曲 Published online: 17 Dec 2014.

Submit your article to this journal $\widetilde{ }$

Џ Article views: 52

Q View related articles $₫$

4 Citing articles: 2 View citing articles 


\section{Innovative power of Dutch secondary education}

\section{Carla Haelermans}

Delft University of Technology, Delft, The Netherlands

\section{ABSTRACT}

This paper analyzes the diffusion and determinants of innovations in secondary education. First, the diffusion path of five clusters of innovations in secondary schools is described. Second, the determinants of the adoption of these innovations are analyzed. The findings show that size is one of the main determinants of share of innovations in a school. Other determinants are competition, school type, and teaching method. These should be factored in innovation in public sector education. This paper explains why.

Keywords: Innovation, education, determinants of innovation, diffusion of innovation, scale effects, innovation policy

\section{INTRODUCTION}

E ducational innovation is a hot topic in international political discussions. It is a major component of the Lisbon agenda (Council of the European Union 2007, European Union 2009) and has been emphasized ever since. The Lisbon strategy has set the goal for Europe 'to become the most competitive and dynamic knowledge-based economy in the world, capable of sustainable economic growth with more and better jobs and greater social cohesion' (High Level Group, chair Wim Kok 2004, p. 8). Investment in human capital development is one of the main topics mentioned to achieve this goal. Another way to achieve the goal is to make use of innovation. Educational innovations are therefore very relevant in achieving that goal.

Innovation in education is argued to improve the international competitiveness of a country (e.g., Cantwell 2006, ch. 20). Moreover, it is said to help to decrease school dropout and improve school quality, performance and skill development (Hoyle and Collier 2006). Consequently, policies to stimulate educational innovations receive a lot of attention and attract vast sums of subsidies.
These policies also require that schools increasingly innovate (Giles and Hargreaves 2006). While little is known about the effectiveness of innovation, it is known that there is great variation between schools in their efforts to innovate. However, it is not known what factors determine this variation. Therefore, this study sets out a descriptive analysis to find determinants that explain the differences in innovative power between organizations.

The aim of this paper is threefold - to:

- Show a diffusion path of specific clusters in Dutch secondary education innovations;

- Research which determinants of innovations matter most; and

- Derive policy implications from this.

This paper contributes to the existing literature by using rather unique Dutch innovation data and by determining what factors have played a role in determining the share of innovations in secondary education. The remainder of this paper is structured as follows: The next section reviews the related literature and necessarily explains the Dutch secondary education sector. A description 
of the data and data sources follows, then the methodology is outlined, after which the results are presented - results with respect both to the diffusion of innovations and to the determinants of innovations. Policy implications and concluding remarks complete this paper.

\section{LITERATURE REVIEW}

This study builds on the literature on innovation, on the literature on determinants of innovation and on the literature on educational innovation. This study also focuses on the problems of connecting innovations to educational outcomes. This paper is primarily based on existing literature on innovation and diffusion of innovation. Basic knowledge of innovation and the diffusion theory of innovation is assumed (see for example, Dosi 2000, Rogers 2003, Stoneman 2001). However, the definition of innovation assumed in this study is that: 'innovation is an idea or process that is new or has substantially changed for that particular organization'.

Literature on determinants of innovation mostly covers the private sector - e.g., chapters in Van Beers et al. (2008) - where HRM, knowledge of employees and employee satisfaction are found to be determinants. $\mathrm{R} \& \mathrm{D}$ activities, financial status of a company and internationalization are also shown to be important factors. Johansson and Forslund (2008: 58-59) address the relationship between determinants and innovation in the effect of urbanization and diversity on innovation. Könings et al. (2007) show that teacher characteristics and the way of teaching influence the innovativeness of a school. An inverted- $U$ relationship between competition and innovation is found by Aghion et al. (2005). The effect of organizational size and innovation is found in Damanpour (1990), Morone and Testa (2008), Shefer and Frenkel (2005), Bettencourt et al. (2007) and Camisón-Zornoza et al. (2004). Based on this literature, teachers, competition, urbanization and school size are expected to be main determinants in public sector innovation as well.

Finally, this paper addresses literature on innovation in (secondary) education; e.g., Machin et al.
(2007) on the impact of ICT investment and change in primary school performance. Using twostage regression analysis, they found a positive relationship between ICT investment and specific performance indicators. Kirschner et al. (2004) examined success factors in educational innovation and arrived at a list of instruments which could determine the success of an innovative education project. Relevant Dutch research on educational innovations appears in Hofman et al. (2007); Hofman et al. give an overview of innovations in the Dutch educational sector, look into the effects of innovation and describe research on innovation in education. They develop a research set up to measure the influence of educational innovations. Their research does not provide empirical evidence on the effect of innovation, but provides a good overview of research in educational innovation and necessary conditions for examining effects of innovations.

Little literature addresses the effect of innovations in education and their impacts - technological change or innovation does not necessarily mean positive change. As Grupp (1998) argues, technological progress is not always improvement; the definition would need a word like 'better' or 'new' to include only positive innovation. Nonetheless, innovation is assumed to have a positive effect on educational performance (Center for Educational Research and Innovation 2008). Some studies investigate the effect of individual innovations, but these studies take mostly place at a micro level at a school, often in a qualitative way [e.g., Dobbins (2009) and Lubienski (2003)]. However, quantitative proof of the effect of innovation on a sector level is lacking.

\section{DUTCH SECONDARY EDUCATION}

Some explanation of the Dutch secondary education sector is necessary to understand choices, explanations and interpretations in this report. In Dutch secondary education four different levels of education are offered. Pupils enter a level of education based on a recommendation given in elementary school. The four different levels of secondary education are: 
- Practical training education (PT, no end terms);

- Prevocational school (PV, four grades);

- Higher general school education (GH, five grades);

- Pre-academic education (PA, six grades).

Most schools offer a combination of these levels of education. However, categorical schools only offering PT, PV or PA exist as well. This study distinguishes seven types of schools, ranging from schools offering solely PT, PV or PA to the so-called comprehensive schools that offer all levels of education.

In The Netherlands, the concept of a school can refer to several levels of aggregation. The highest level of aggregation is the governing body. A governing body manages or administrates several schools. There used to be a one-on-one relationship between the school and the governing body. However, in the 1990's the Dutch government stimulated an increase in scale. As a result, it is now quite common that a governing body represents more than one school. The second level of aggregation is the school as an organization with one or more branches. This is the unit of observation in this research. Most schools have one or more branches. At the lowest level a branch itself might be referred to as a school.

An important aspect for this research is that most schools teach traditionally with one teacher teaching one group of pupils in one classroom. In this setting communication is mostly unidirectional: the pupils listen while the teacher speaks. Some schools are moving towards a more modern teaching method in which thinking for oneself, independent group work and own initiative of the pupils are the keywords.

\section{DATA}

This study uses panel data on Dutch secondary schools covering the school years 2002/03 to $2007 / 08$. For convenience, the school year 2002/03 is referred to as 2002 , to $2003 / 04$ as 2003 and so on. This study distinguishes three types of data: school characteristics, environmental characteristics and innovation data. School characteristics are for example the school type and the way of teaching. Environmental characteristics are for example competition and the degree of urbanization. The school and environmental characteristics are obtained from several existing administrative registrations from $\mathrm{CFI}^{1}$ and Statistics Netherlands. The innovation data are gathered by means of a questionnaire.

The innovation questionnaire was sent to the management of 593 Dutch secondary schools. The questionnaire consists of 132 listed innovations and some general questions. The list of innovations is composed very carefully, based on literature on innovations in Dutch education, and interviews with school directors from 15 Dutch secondary schools. School directors were asked to fill out whether the school had introduced a specific innovation, and if so in what year. There was also room to mention other innovations that were not incorporated in the list. In the end, 155 school directors filled out the questionnaire, of which 153 remained after a data check and data manipulation.

\section{TABle 1: Response among Dutch secondary SCHOOLS}

\begin{tabular}{lccc}
$\begin{array}{l}\text { School size } \\
\text { and type }\end{array}$ & $\begin{array}{c}\text { Total no. } \\
\text { schools }\end{array}$ & Response $(\boldsymbol{n})$ & $(\%)$ \\
\hline Size & & & \\
\hline$\leq 1500$ pupils & 332 & 90 & 27 \\
$>1500$ pupils & 261 & 63 & 24 \\
\hline Type & & & \\
\hline PT & 71 & 18 & 25 \\
PV & 58 & 16 & 28 \\
PT/PV/GH/PA & 53 & 21 & 40 \\
PV/GH/PA & 319 & 75 & 24 \\
GH/PA & 38 & 8 & 21 \\
PA & 37 & 11 & 30 \\
Other & 17 & 4 & 24 \\
\hline Total & 593 & 153 & $\mathbf{2 6}$ \\
\hline
\end{tabular}

1 CFI is an organization owned by the Ministry of Education that collects data on schools and provides the budget for schools and gives them information on their used resources, pupils and pupil performances. 
Table 1 shows the response analysis of the sample compared to the entire population. First, a distinction is made between schools with less than 1500 pupils and schools that exceed 1500 pupils. Second, the table shows a comparison based on school type. Table 1 shows that there is a quite evenly distribution with respect to school size. In regard to school type there is a slight overrepresentation of PT/PV/GH/PA-schools and a slight underrepresentation of GH/PA-schools in the sample.

The next step is to test for the representativeness of the sample using logit analysis. A logit model is a binary choice model which predicts whether the chance of having a specific outcome is dependent on certain characteristics. The logit

\section{TABle 2: Representativeness OF the SAMPLE - LOGIT ANALYSIS}

\begin{tabular}{lcc} 
Variable & Odds ratio & $P$-value \\
\hline Constant & 0.451 & 0.002 \\
Number of branches & 1.015 & 0.732 \\
Size school & 1.000 & 0.782 \\
Number of schools per & 1.004 & 0.419 \\
governing body & & \\
Province in the Netherlands & 0.982 & 0.213 \\
Solely PV or PT & 1.142 & 0.476 \\
Solely GH or PA & 1.003 & 0.983 \\
School type & 1.019 & 0.511 \\
Degree of urbanization & 0.992 & 0.000 \\
\hline
\end{tabular}

analysis suits the data very well, since this analysis makes it possible to test whether the chance of being present in the sample is dependent on school characteristics and environmental variables. The explanatory variables used in the analysis are the number of branches, the size of the school represented by the number of pupils, the number of schools in the governing body, the province in the Netherlands the school is located, whether it is solely a PV/PT school or solely a GH/PA school, the school type and the degree of urbanization. Table 2 shows the odds ratios of the logit analysis. Table 2 shows that most of the variables are not significant at the 5\%-level. This indicates that the chance of being present in the sample is not dependent on those variables. However, there is a significant constant and a significant degree of urbanization. The selection bias probability of the degree of urbanization is 0.99 , which makes the sample a little overrepresented by schools in a less urban area. The chi-square of the individual variables is significant at the $1 \%$ level. Based on this the conclusion is that the sample is almost, but not entirely, representative of the entire population. In the remainder of this research, the inverse probability weighting (IPW) is used to control for this. IPW uses the inverse of the estimated selection bias probability to correct for the bias. For detailed information on IPW see Sullivan Pepe (2004, ch. 7) and Wooldridge (2002, ch. 17).

TABLE 3: Weighted SAMPLE DESCRIPTIVES OF RELEVANT VARIABLES, 2007 (153 schools)

\begin{tabular}{|c|c|c|c|c|}
\hline & Mean & Std. Dev. & Min & Max \\
\hline School size & 1521.02 & 1084.73 & 78 & 5971 \\
\hline Degree of urbanization & 43.42 & 33.20 & 0 & 97.86 \\
\hline Number of schools per municipality & 1.39 & 0.84 & 1 & 5 \\
\hline Number of branches & 1.95 & 1.59 & 1 & 8 \\
\hline Number of schools per governing body & 5.89 & 8.06 & 1 & 31 \\
\hline Average age teachers & 45.61 & 2.29 & 37.13 & 54.39 \\
\hline Share of male teachers (\%) & 58.85 & 6.78 & 27.75 & 83.65 \\
\hline Average experience teachers (in years) & 19.86 & 3.28 & 0.5 & 26.54 \\
\hline Traditional way of teaching ( $1=$ yes, $0=$ no) & 0.72 & 0.45 & 0 & 1 \\
\hline Practical/pre-vocational $(1=$ yes, $0=$ no) & 0.24 & 0.43 & 0 & 1 \\
\hline Higher general/pre-academic ( $1=$ yes, $0=$ no) & 0.12 & 0.32 & 0 & 1 \\
\hline Amount of innovations present & 43.85 & 14.62 & 5 & 78 \\
\hline
\end{tabular}


Table 3 provides insight to the data set of 153 schools and shows the weighted sample descriptives. The school size varies from 78-5971 pupils. This is the difference between a school that only started recently and an old school with several branches in an intensely urban area (e.g., Amsterdam). The sample includes some schools from very urban areas and also some schools from very rural areas of the Netherlands. Furthermore, branches per schools varies from 1-8 (av. 2), the number of schools per governing body varies from 1-31 (av. 6). The share of male teachers varies from $28-81 \%$. Average experience of the teacher is 20 years. In the sample, $72 \%$ of the schools still have a traditional way of teaching. Table 3 shows that $24 \%$ of schools offer solely practical training education or prevocational education and that $12 \%$ of schools offer only higher general education or pre academic education. The remaining $63 \%$ are comprehensive schools. Finally, in 2007, 44 (avg.) innovations are applied by schools.

\section{INNOVATIONS}

For proper interpretation of the results this study categorizes the individual innovations. The 132 individual innovations are divided over five clusters of innovations, ${ }^{2}$ based on the content of innovations. These five clusters are related to educational policy subjects that have been important in the past few years.

This study distinguishes the following five clusters of innovations. Note that the maximum number of innovations belonging to a cluster is mentioned in parentheses.

- New courses/profiling (29);

- Pedagogical/didactical (40);

- Process (35);

- Professionalization of teachers (16);

- Education chain (12).

Innovations in the new courses/profiling cluster are related to the introduction of new courses, like new mathematics courses, to language innovations like bilingual education and to the profile of school, for example a sports school or a culture school. Pedagogical/didactical innovations are innovations mainly at the content of the courses and the way classes are taught. The pedagogical/ didactical innovations also include the services a school makes use of (e.g., psychologist, dyslexia specialist), projects and pupil innovations, like pupils as coaches or development plans for pupils. Process innovations are for example IT, infrastructural (e.g., a totally new building) and organizational innovations. Innovations with respect to the professionalization of the teacher include all innovations that are related to the teaching staff. Lastly, education chain innovations mainly refer to innovations arising from collaborations between the secondary school and for example elementary schools, universities or business companies.

The value of a cluster is determined by the total amount of innovations present at a school belonging to that cluster in a certain year. The value in the next year is the number of newly introduced innovations during that year added to the value of the previous year.

\section{DETERMINANTS}

Several determinants may be related to a school's choice to introduce a certain innovation. The determinants evaluated in this research are carefully chosen from the literature. First, factors which the literature shows to influence innovations are used as determinants. Further, factors that are suspected have an influence on the innovativeness of the school are added. The degree of urbanization is corrected for the bias by inverse probability weighting.

The following possible determinants are analyzed:

- school size (number of pupils);

- number of branches;

- number of schools per governing body;

- competition ${ }^{3}$;

2 A complete overview of all individual innovations is available upon request from the author.

3 Competition is estimated as the number of schools per 10,000 inhabitants in a municipality. 
- school type;

- school has a traditional way of teaching;

- average experience of the teachers;

- share of male teachers;

- degree of urbanization.

\section{Methodology}

Descriptive analysis is used to assess what determinants play a role in the innovativeness of a school, using a logistic transformation. For every cluster of innovations a separate regression is used. The simple regression includes the determinants and an information variable. The information variable assembles the information available to the management of a school on new and upcoming innovations. The value of the information variable is determined by the average amount of new innovations introduced in that year.

This method assumes a linear relationship between the variables, normally distributed variables and homoscedasticity. The method fits the dataset rather well, since there is a normal distribution and homoscedasticity and it is likely that there are linear relationships. Furthermore, the regression is perfect to answer the research question, since it makes it possible to determine the factors that influence the share of innovations in a certain cluster at a school. In other words, it shows the reason for differences in innovative power between schools. However, one should note that in this methodology the assumption is made that innovations have a positive effect on education.

The share of innovations in cluster $c$ is the following:

$P_{c}=\frac{1}{1+\exp -\left(\alpha_{c}+\sum_{x} \beta_{c x} \cdot \operatorname{Det}_{x}+\gamma_{c t} \cdot \text { info }+u_{c}\right)}$

with:

$P_{c} \quad=$ the share of innovations in cluster $c$;

$c \quad=$ cluster of innovations;

Det $_{x} \quad=$ determinant $x$;

info = information variable;

$u_{c} \quad=$ error term of estimation $c$;

$\alpha_{c}, \beta_{c}, \gamma_{c}=$ estimated parameters.
For estimation convenience, equation 1 is rewritten to:

$\log \left(\frac{P_{c}}{1-P_{c}}\right)=\alpha_{c}+\sum_{x} \beta_{c x} \cdot \operatorname{Det}_{x}+\gamma_{c t} \cdot \operatorname{info}+u_{c}(c=1, \ldots, C)$

Equation 2 shows the regression of the determinants on the share of innovations in a certain cluster. Equation 2 is estimated with least squares. Since the parameters of this regression are hard to interpret, the marginal probabilities are calculated as well. The marginal probability is shown in equation 3 .

$M C_{c x}=\beta_{c x} \cdot P_{c} \cdot\left(1-p_{c}\right)$

\section{RESULTS}

\section{Diffusion of innovations}

The diffusion figure shows how the innovation clusters have developed over the years. Figure 1 depicts the diffusion rate of the innovation clusters. The diffusion rate is calculated by comparing the average number of innovations per cluster per year for all the schools to the maximum amount of innovations per cluster. For example, if a cluster has a maximum of 15 innovations and the average amount of introduced innovations is 6 , then the diffusion rate is $40 \%$.

The maximum amount of innovations per cluster is determined by the sum of the innovations in the questionnaire and the innovations added to the questionnaire by the schools for a specific cluster. As indicated above, the list of innovations is very carefully composed. Furthermore, the fact that schools could add missing innovations to the list should lead to a representative maximum amount of innovations in the clusters. However, the author realizes that not all schools have participated in the study and that therefore some very specific innovations, which could have changed the maximum amount of innovations for a cluster, could have been missed. It is probable that other innovations exist at schools that have not taken part in the questionnaire. In this study, these particular 
innovations could not be taken into account. Also, the lack of specific data on the innovations that schools have introduced makes it not possible to distinguish between many small innovations (which may be less effective) and a few large innovations which lead to major changes. Inevitably, the figure on the diffusion of innovations is solely based on the amount of innovations.

Figure 1 shows that not all innovation clusters have had the same diffusion rate during these six years. The curve for innovations with respect to new courses/profiling is the flattest curve. Furthermore, this cluster also had the lowest growth between 2002 and 2009. Innovations increased by a little over $16 \%$ points. There was an increase of $29 \%$ points in process innovations, $20 \%$ points in pedagogical/didactical innovations and $28 \%$ points in education chain innovations. The innovations with respect to the professionalization of the teachers have encountered the highest increase, of about $40 \%$.

Figure 1 also shows that innovation with respect to the professionalization of the teachers is best dif- fused over schools, with $>55 \%$ in 2009 . Innovations with respect to new courses/profiling are least diffused, compared to the other 4 clusters. One has to keep in mind, however, that not all innovations are applicable to all types of schools. Some innovations are for example specifically meant for categorical schools and therefore cannot be introduced by comprehensive schools.

Lastly, Figure 1 shows a large increase in 2006 for process innovations, educational chain innovations and innovations with respect to the professionalization of teachers. The questionnaire, which includes the individual innovations, shows that the process innovations increase is mainly due to IT innovations, like digital school boards, digital exams and an electronic learning environment. Furthermore, the increase in innovations with respect to the professionalization of teachers seems to be due to increased working in teams, the role of the teacher as a coach and the electronic competency file. The increase in education chain innovations is mainly due to projects with universities and elementary schools.

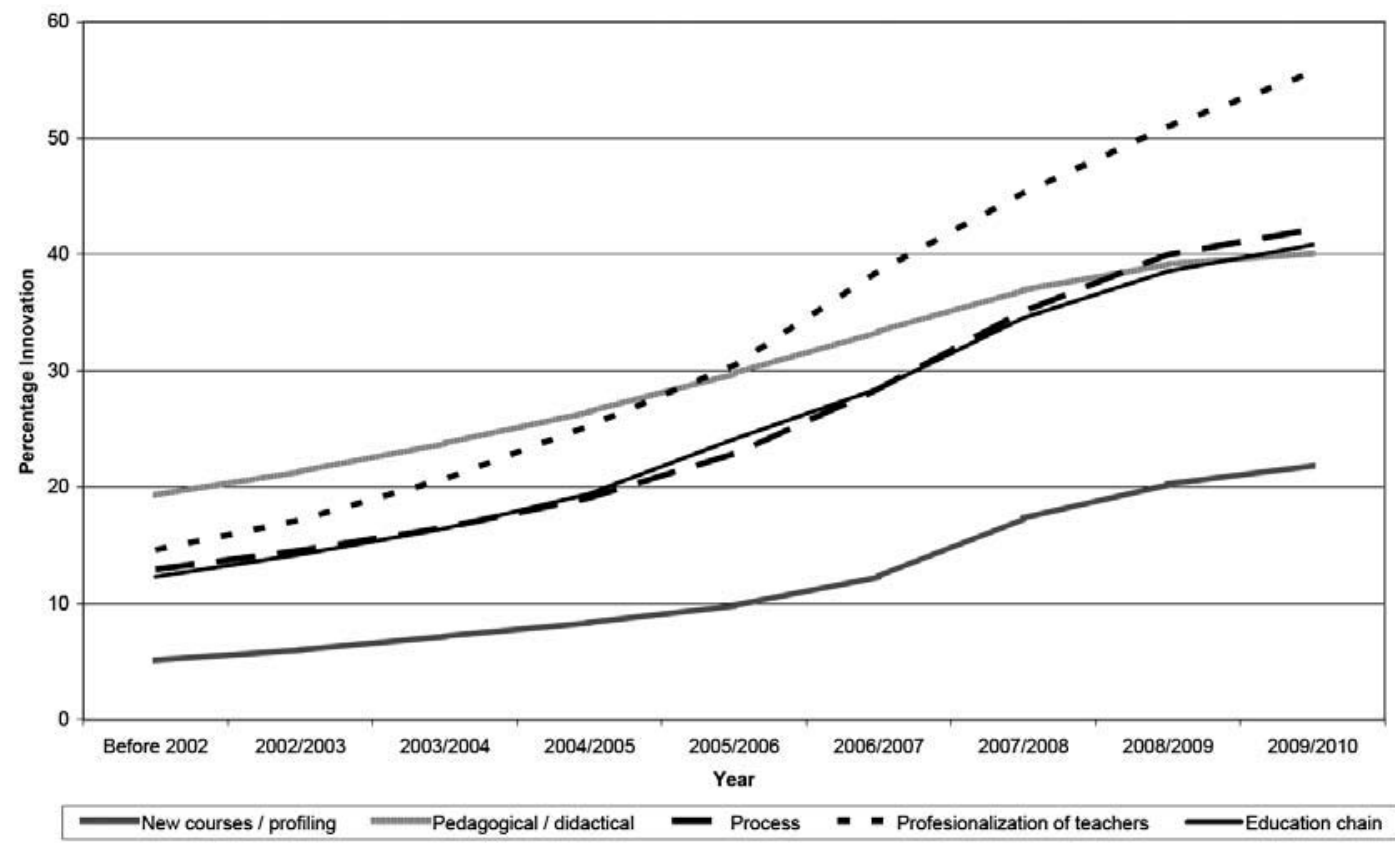

Figure 1: Percentage diffusion of innovation Clusters (2002-2009). 


\section{Determinants of innovations}

To determine the influence of the determinants on the share of innovations within one cluster first the regression is estimated, after which the marginal effects of the variables in this regression are calculated. The regressions show that the information variable is positive and significant for all five innovation clusters. This positive significant effect indicates that there is a deceleration in the information available to schools. Innovation information is not available to all schools at once. Schools need time to get informed on innovations. The information variable might then not only include information on the existence of a certain innovation, but also on the costs and of this innovation.

Table 4 shows the results of estimation of marginal effects for all share determinants of applied innovations in a certain cluster. Table 4 indicates that size is related to the innovativeness of a school. This relation is the threefold influence of:

- school size influence;

- an extra branch;

- belong to a larger governing body.

With respect to the school size, Table 4 illustrates that there is a positive significant effect on all innovation clusters. The effect per 1000 pupils varies from a $0.8 \%$ higher share of new courses/ profiling innovations to a $6 \%$ higher share for professionalization of the teachers' innovations. Table 4 furthermore shows that there is a negative significant relation between the number of branches and most of the innovation clusters. This effect varies from $0.4-2.6 \%$ lower share of innovations in a certain cluster.

The last size effect is the number of schools in a determinant's governing body. The number of schools per governing body is positively related to process innovations $(0.1 \%$ higher share) and education chain innovations ( $0.3 \%$ higher share). There is a negative relation between the number of schools per governing body and the share of innovations in the professionalization of teachers cluster. Schools belonging to smaller governing bodies, that may have less joint organizational agreements, apparently choose to work more on the professionalization of the teacher.

Table 4 suggests that competition has a significant effect on process innovations and on pedagogical/didactical innovations. The share of innovations of a school in a municipality with 10,000 inhabitants and two competitors is applies pedagogical/didactical innovations is $6.8 \%$ higher than of a school in the same municipality with only one competitor. This share difference is $4.1 \%$ for process innovations. Schools seem to compete mostly in educational content to make a difference.

TAble 4: MARginal effects of Relation determinants AND INNOVATION Clusters, 2002-2007

\begin{tabular}{|c|c|c|c|c|c|}
\hline & $\begin{array}{l}\text { New courses/ } \\
\text { profiling }\end{array}$ & $\begin{array}{c}\text { Pedagogical/ } \\
\text { didactical }\end{array}$ & Process & $\begin{array}{l}\text { Professional- } \\
\text { ization of } \\
\text { teachers }\end{array}$ & $\begin{array}{l}\text { Education } \\
\text { chain }\end{array}$ \\
\hline School size (per 1000 pupils) & $0.008 * *$ & $0.029 * \star \star$ & $0.047 * \star \star$ & $0.060 * * \star$ & $0.033 * * \star$ \\
\hline Number of branches & -0.004 * & -0.005 & $-0.026 * \star \star$ & $-0.024 * \star \star$ & -0.013 *** \\
\hline Number of schools per governing body & $y-0.000$ & -0.000 & 0.001 * & -0.001 * & $0.003 * * \star$ \\
\hline Competition & -0.006 & $0.068 * \star \star$ & $0.041 * \star$ & 0.026 & 0.013 \\
\hline Solely PV or PT & $-0.020 * \star \star$ & 0.002 & -0.018 & 0.042 ** & $-0.060 * \star \star$ \\
\hline Solely GH or PA & 0.013 * & 0.035 * & $0.049 * \star \star$ & $0.097 * \star \star$ & -0.001 \\
\hline Traditional way of teaching & $-0.029 * \star \star$ & $-0.049 * \star \star$ & -0.015 & $-0.075^{\star \star \star}$ & -0.001 \\
\hline Average experience of the teachers & 0.001 ** & $0.005 * \star \star$ & $0.004 * \star$ & 0.003 & -0.001 \\
\hline Share male teachers & -0.032 & $-0.004 * \star \star$ & $-0.002 * \star \star$ & -0.001 & -0.000 \\
\hline Degree of urbanization (per 10\%) & 0.002 * & -0.001 & -0.003 * & -0.002 & $-0.005 * * \star$ \\
\hline
\end{tabular}

$\star \star \star=$ significant at the $1 \%$ level; ${ }^{\star \star}=$ significant at the $5 \%$ level; ${ }^{*}=$ significant at the $10 \%$ level 
In the regression there are three school types distinguished: the PV/PT schools, the GH/PH schools and the comprehensive schools. The schools that solely offer PV and/or PT have a lower share of innovations with respect to new courses/profiling and education chain innovations, and a higher share of innovations with respect to the professionalization of teachers. Schools offering solely GH and/or PA are positively related to all innovation clusters except the education chain. This indicates that schools offering $\mathrm{PV} / \mathrm{PV}$ are working more on educational content, whereas schools with the higher education levels are working more on improving processes and the methodology of teaching. Compared to the comprehensive schools, both other types seem to put more effort into increasing the professionalization of the teacher.

From Table 4 one can see that the way of teaching and the type of teachers also have an effect on innovations. Having a traditional way of teaching is negatively related to three of the five innovation clusters. Furthermore, the results show that the experience of teachers is positively related to three innovation clusters. Also, the share of male teachers is negatively related to pedagogical/didactical and process innovations.

\section{CONCLUSION AND DISCUSSION}

This study investigates the diffusion of innovations and the determinants of innovations in Dutch secondary education. A questionnaire is set out to gather information on innovations at secondary schools and relate these to existing school- and environmental information. In this research, five clusters of innovations are distinguished, namely: new courses/profiling; pedagogical/didactical innovations; process innovations; professionalization of the teachers; and education chain innovations. This study shows the diffusion path and investigates the determinants of all five clusters.

This is a rather unique dataset which gives information on innovations present in Dutch secondary schools. Furthermore information is included on the characteristics of the school and the environ- ment. This altogether makes it possible to calculate the odds ratio of the share of innovations per cluster. Then a logistic transformation is used to regress the determinants on the share of applied innovations in a certain cluster. The results show that scale, competition, school type and the way of teaching are the main determinants of innovations. Larger schools, in a more competitive environment with a progressive way of teaching seem to innovate more. The influence of school type is mixed.

The main policy advice from the Lisbon agenda is for countries to work on decreasing educational dropouts, increase average reading skills, stimulate life-long-learning and increase general skill development. These factors are said to be influenced by innovations, although for now, proof for this statement is lacking. However, if we assume that innovations may help reaching the Lisbon goals, the policy implications from this research give some options in how to stimulate innovations.

But, before elaborating on simulating policies, some general remarks are necessary. This descriptive analysis only investigates the diffusion and determinants of innovations, not at the effects and effectiveness of innovations. It is possible that future research will show that innovations are mainly used for cosmetic reasons, cost a lot of money and may not contribute to a higher quality or a higher performance at all. If this turns out to be the case, the results of this study can also be used for innovation restraining policies.

The results show a positive relation between innovations and size, where size is a combination of the large positive effect of school size and the smaller negative effect of the number of branches. One reason for this negative effect could be that the number of pupils per branch is smaller when there is more than one branch. The negative sign then decreases the positive effect of the school size. Another explanation is that having more branches implies having more decision-making units. This might lead to a more complicated process on the decision to innovate, which could slow down the innovation pace. The positive relation of scale is in line with existing literature (e.g., Camisón-Zornoza 
et al. 2004, Bettencourt, Lobo and Strumsky 2007, Shefer and Frenkel 2005). Scale often is related to making an organization more professional. This in turn might be related to having more information available on innovations and the expected costs of innovations. Larger organizations furthermore have more resources, which might enable them to work on more innovations. As policy advice, it would first of all be wise to detect why small schools seem to innovate less. Furthermore, the advice is to stimulate smaller schools to innovate. Another option is to stimulate governing bodies with only one school to collaborate with other governing bodies. A third suggestion is to introduce specific innovation programs and subsidies for small schools.

Another policy implication is that the school type and the way of teaching have to be taken into account explicitly, when stimulating or slowing down innovations. The diversity of schools, also with respect to their teaching staff, seems to play a major role in innovation. The diversity of (educational) institutions and the importance of diversity are also stressed by Ostrom (2005). To increase diversity, it might be advisable to stimulate schools to have a good mix of teachers with respect to sex and experience. Furthermore, schools should be stimulated to lessen the traditional way of teaching and become more progressive, without losing their identity. It might also be wise to ask the opinion of a diverse range of schools when developing new innovation policy for education.

Next, this study finds that competition stimulates innovation. It may be advisable to stimulate new entrance of schools and stimulate schools to diversify. However, it is important to note that there might be some tension between policies stimulating an increase in scale and policies stimulating an increase in competition. A healthy balance is needed in both increasing scale and increasing competition, making sure that governing bodies and schools are not too small or too big. There might also be some tension with respect to the positive effect of both size and the diversity of schools. Increasing size might in fact decrease diversity, which is why a healthy balance is needed here as well. Therefore, one should be careful just increasing the size, since this might have undesired side effects which make the innovation rate decrease.

The results show that a larger governing body has a positive marginal effect on the process innovations and on the education chain innovations. A reason for the latter could be that there is a large collaboration between the governing body and other schools (elementary schools or higher education) and businesses in the area. The governing bodies may be stimulating their schools to make use of this collaboration. It is also likely that a governing body intensively interferes in the processes at the schools and stimulates the schools to have similar processes and learn from each other. Furthermore, a traditional way of teaching is negatively related to new courses/profiling, pedagogical/didactical and professionalization of the teacher innovations. Schools with a traditional way of teaching seem to be less open to innovation and change, and apparently stick more to 'the way it has always been'.

The results also indicate that the average years of teaching experience is positively related to new courses/profiling, pedagogical/didactical and process innovations. Furthermore, a higher share of male teachers is negatively related to the pedagogical/didactical and process innovations. The latter seems to indicate that female teachers are more progressive and more open to innovation and change with respect to the way of teaching and the used processes. It might also be the case that females are more willing to obey new ideas and suggestions from their superior compared to males. It furthermore seems that some level of experience is positively related to the number of innovations at a school. A possible reason for this is that more experienced teachers may be better embedded in the system and have a more stable working situation, whereas teachers with less experience may need some years to fully adapt. More stable teachers may be up for the change and more willing to put effort into the introduction of an innovation and making it a success. It 
seems that some experience is needed to be ready for innovations and major changes.

One weakness of the study is the list of determinants. Other determinants might be of influence on the decision to innovate as well (e.g., governing body characteristics, productivity and costs variables). However, some of these determinants are not measurable in a way that makes them suitable to include in this study. Other potential determinants cannot be included because data is not available on these determinants.

This research is a good base for showing the diffusion path and determinants of the innovation clusters. However, in future research, the innovations should be empirically related to the performance of a school. Costs, expenditures and the pupil performance can then be taken into account as well. Only if such research is carried out it can become clear what the effect is of innovations in secondary education and whether it is wise to invest in and stimulate innovations.

\section{References}

Aghion P, Bloom N, Blundell R, Griffith R and Howitt P (2005) Competition and innovation: an inverted-U relationship. The Quarterly Journal of Economics 120: 701-728.

Bettencourt LMA, Lobo J and Strumsky D (2007) Invention in the city: Increasing returns to patenting as a scaling function of metropolitan size, Research Policy 36: 107-120.

Camisón-Zornoza C, Lapiedra-Alcamí R, SegarraCiprés M and Boronat-Navarro M (2004) A meta-analysis of innovation and organizational size, Organization Studies 25: 331-361.

Cantwell J (2006) Innovation and competitiveness, In Fagerberg J, Mowery D and Nelson R (Eds.) The Oxford Handbook of Innovation. Oxford University Press, Oxford.

Center for Educational Research and Innovation (2008) Innovating to learn, learn to innovate, In OECD (ed.) OECD, Paris.

Council of the European Union (2007) Strategic report on the renewed Lisbon strategy for growth and jobs: launching the new cycle (2008-2010) Keeping up the pace of change. Accessed at http://ec.europa.eu/growthandjobs/pdf/european -dimension-200712-annual-progress-report/ 200712-annual-report_en.pdf on 22 July, 2009.
Damanpour F (1990) Organizational size and innovation, Organization Studies 13: 375-402.

Dobbins K (2009) Feeding innovation with learning lunches: Contextualizing academic innovation in higher education. Journal of Further and Higher Education 33: 411-422.

Dosi G (2000) The research on innovation diffusion: An assessment. In Dosi G (ed.) Innovation, organization and economic dynamics, Edward Elgar, Cheltenham.

European Union (2009) Lisbon Strategy. Accessed at http://europa.eu/scadplus/glossary/lisbon_strateg y_en.htm on 22 July 2009.

Giles C and Hargreaves A (2006) The sustainability of innovative schools as learning organizations and professional learning communities during standardized reform, Educational Administration Quarterly 42: 124-156.

Grupp H (1998) Foundations of the economics of innovation, Edward Elgar, Cheltenham.

High Level Group chaired by Wim Kok (2004) Facing the challenge: The Lisbon strategy for growth and employment. European Council, Brussels.

Hofman WHA, Hofman RH, Dijkstra BJ, de Boom J and Meeuwisse M (2007) Innovaties in het voortgezet onderwijs: Een verkenning van innovaties en effecten in het voortgezet onderwijs. Groningen / Rotterdam, UOCG \& GION / RISBO Contract Research BV.

Hoyle JR and Collier V (2006) Urban CEO superintendents' alternative strategies in reducing school dropout, Education and Urban Society 39: 69-90.

Johansson B and Forslund U (2008) The analysis of location, co-location and urbanization economies, In Karlsson C (ed.) Handbook of Research on Cluster Theory. Edward Elgar, Cheltenham.

Kirschner PA, Hendriks M, Paas F, Wopereis I and Cordewener B (2004) Determinants for success and failure of educational innovation projects EDUCAUSE Annual Conferences. Denver, CO.

Könings KD, Brand-Gruwel S and van Merriënboer JG (2007) Teachers' perspectives on innovations: Implications for educational design, Teaching and Teacher Education 23: 985-997.

Lubienski C (2003) Innovation in education markets: Theory and evidence on the impact of competition and choice in charter schools, American Educational Research Journal 40: 395-443.

Machin S, McNally S and Silva O (2007) New technologies in schools: Is there a payoff? The Economic Journal 117: 1145-1167.

Morone P and Testa G (2008) Firms growth, size and innovation: An investigation into the Italian 
manufacturing sector, Economics of Innovation and New Technology 17: 311-329.

Ostrom E (2005) Understanding institutional diversity, Princeton University Press, Princeton NJ.

Rogers EM (2003) Diffusion of innovations, The Free Press, New York.

Shefer D and Frenkel A (2005) R\&D, firm size and innovation: an empirical analysis, Technovation 25: 25-32.

Stoneman P (2001) The economics of technological diffusion, Oxford University Press, Oxford.
Sullivan Pepe M (2004) The statistical evaluation of medical tests for classification and prediction, Oxford University Press, Oxford.

Van Beers C, Kleinknecht A, Ortt R and Verburg R (2008) Determinants of innovative behavior: A firm's internal practices and its external environment, Palgrave Macmillan, New York. Wooldridge J (2002) Econometric analysis of crosssection and panel data, MIT Press, Cambridge, MA.

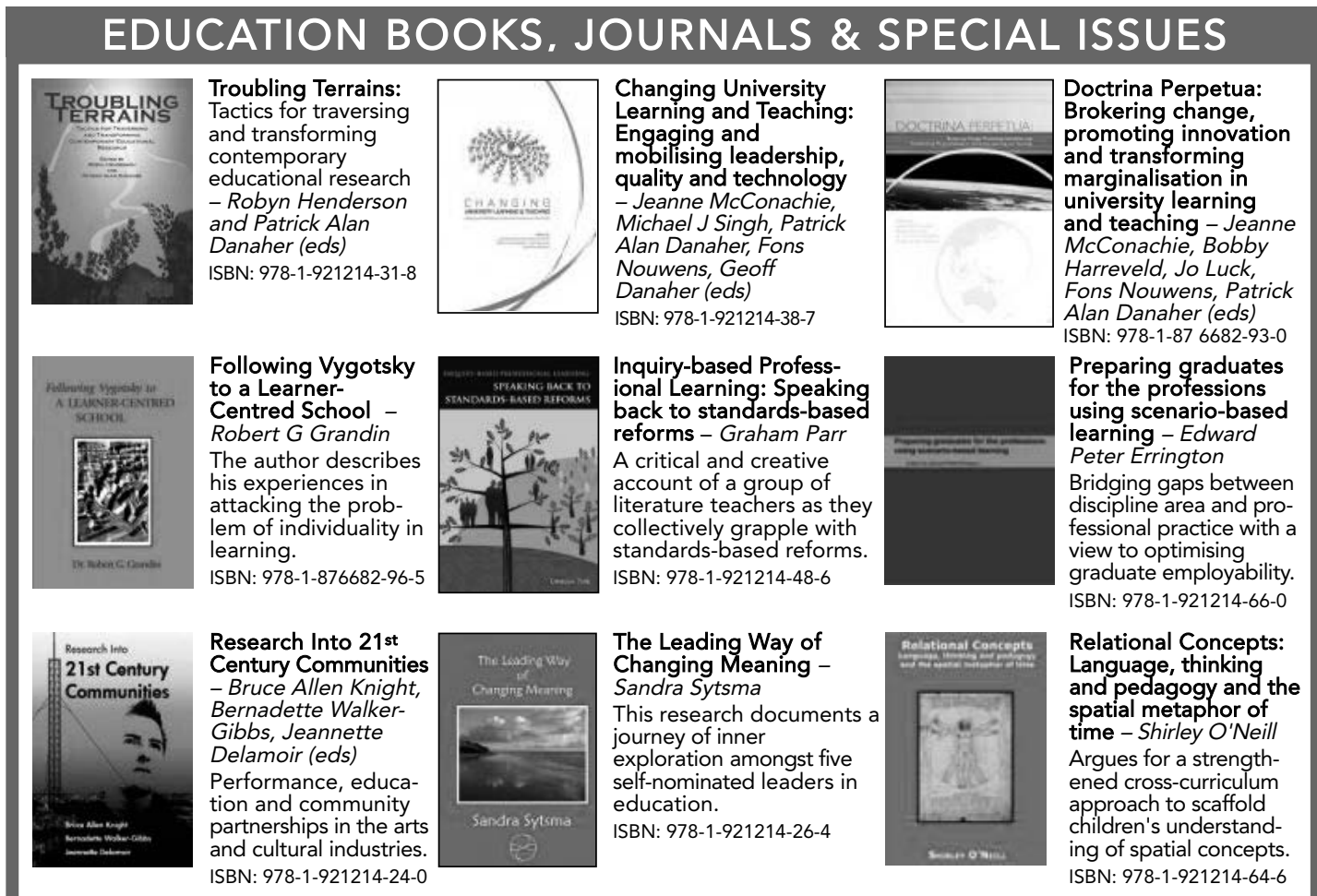

\section{JOURNAL SPECIAL ISSUES}

Sea Changes, Tree Changes and Bush Lessons: Post-compulsory Education and Rural Renewal Special Issue of Rural Society

Volume 19 Issue $2 \sim$ August $2009 \sim$ ii +108 pages ISBN 978-1-921348-19-8

Editors: Geoff Danaher and Bobby Harreveld, Central Queensland University and Patrick Alan Danaher University of Southern Queensland

Published in collaboration with the Australian Association of Social Workers
Re-conceiving the Artful in Management Development and Education

Special Issue of Journal of Management \& Organization Volume 14 Issue 5 November $2008 \sim$ ii +126 pages ISBN 978-0-9775742-6-1

Editors: Cheryl Kerr, Centre for Learning Innovation, Faculty of Education, Queensland University of Technology, Australia and Lotte Darsø, The Creative Alliance, Learning Lab Denmark, Danish University of Education

\section{JOURNALS}

International Journal of Training Research

Research journal of the Australian Vocational Education and Training Research Association (AVETRA)

ISSN 1448-0220 2 issues per year ERA Rank B (80 pg average) Editor: Peter Kell, Centre for Lifelong Learning Research and Development, The Hong Kong Institute of Education
International Journal of Pedagogies \& Learning

Research journal of the Internationla Society for Leadership in Pedagogies \& Learning (ISLPL)

ISSN 1833-4105 3 issues per year ERA Rank A (100 pg average) Editors: Patrick Alan Danaher, Shirley O'Neill and Jeong-Bae Son, Faculty of Education, University of Southern Queensland, Australia 